\title{
TOTAL ANTIOXIDANT ACTIVITY OF PLANTS OF SYMPHYTUM L. SPECIES
}

\section{Vergun Olena ${ }^{1 *}$, Brindza Jan $^{2}$, Rakhmetov Djamal ${ }^{1}$}

\author{
${ }^{1}$ M.M. Gryshko National Botanical Garden of NAS of Ukraine, Kyiv, Ukraine \\ ${ }^{2}$ Institute of Biodiversity Conservation and Biosafety, Slovak University of Agriculture in Nitra, Slovak Republic
}

The aim of this study to demonstrate the antioxidant potential of methanolic, ethanolic and aqueous extracts of plants of Symphytum L. species. The DPPH radical scavenging effect was assessed by the discoloration of methanol solution of 2.2-diphenyl-1-picrylhydrazyl after 10 minutes according to Brand-Williams et al. (1995). Total antioxidant activity (TAA) of above-ground part of Symphytum asperum Lepech. during vegetation was from $73.59 \%$ (at spring vegetation stage) to $79.65 \%$ (fruiatage) in methanolic extracts, from $17.53 \%$ (budding stage) to $36.31 \%$ (spring vegetation stage) - in ethanolic extracts, from $59.64 \%$ (spring vegetation stage) to $76.15 \%$ (stage of stem growth) - in water extracts. Methanolic extracts of Symphytum caucasicum Bieb. showed the TAA from $75.48 \%$ (budding stage) to $80.81 \%$ (spring vegetation stage), ethanolic extracts - from $22.61 \%$ (blossoming stage) to $73.99 \%$ (spring vegetation stage), water extracts - from $67.46 \%$ (budding stage) to $74.45 \%$ (blossoming stage). In plant raw material of Symphytum $\times$ uplandicum Nyman TAA was from $16.24 \%$ (blossoming stage) to $79.18 \%$ (budding stage) in methanolic extracts, from 5.64\% (blossoming stage) to $21.06 \%$ (budding stage) - in ethanolic extracts, from $17.23 \%$ (stage of stem growth) to $60.58 \%$ (budding stage) - in water extracts. Maximal sign of radical inhibition was noticed in methanolic extracts of Symphytum caucasicum in stage of spring vegetation and minimal - in ethanolic extracts of Symphytum $\times$ uplandicum in blossoming stage. Obtaned data allow to use these plants as plant raw material with antioxidant potential.

Keywords: Symphytum spp.; antioxidant activity; DPPH-method; methanol; ethanol; aqueous extracts

\section{Introduction}

Medicinal plants have been used in the cure of human diseases due to their content of components with antioxidant value. Antioxidants are a group of different natural compounds in the human body which are important for protection against the harmful effects of free radicals (Tahirovic et al., 2014). Plants of genus of Symphytum L. are species widely used in traditional and folk medicine. Plant raw material of these plants is a rich source of biological activity compounds such as allantoin, mucopolysaccharides, flavones, steroidal saponins, alkaloids, macro elements, amino acids, phenolic acids with anticancer and antioxidant action (Roman et al., 2008; Vergun, 2008; Castro et al., 2001; Stef et al., 2010; Vergun and Rakhmetov, 2013). Savic et al. (2012) reported that ethanol extracts of the underground part of Symphytum officinale L. showed the DPPH radical scavenging $77.3 \%$. The results obtained by Paun et al. (2012) showed over $80 \%$ DPPH inhibition by the concentrated extracts of underground part of Symphytum officinale. Puertas-Mejia et al. (2012) determined in the ethanol extracts of leaves the antiradical activity 49.94\%. According to Stef et al. (2010) the antioxidant

*Corresponding author: Olena Vergun, M.M. Gryshko National Botanical Garden of Ukraine of National Academy of Sciences, Kyiv, Ukraine, $\bowtie$ en_vergun@ukr.net 
activity of extracts of Symphytum officinale was 36.3\%. From the leaves Symphytum asperum Lepech. and Symphytum caucasicum Bieb. identified high molecular weight fractions with anticomplement and antioxidant activity which might be used as anti-inflammatory and wound-healing agents (Barbakadze et al., 2011). Alkan et al. (2014) obtained data that percentage of inhibition of the DPPH radical was varying from 38.72 to $85.09 \%$ in ethanolic extracts and from 21.68 to $52.19 \%$ in aqueous extracts of leaves.

In present study we are interested to quantify the total antioxidant capacity of above-ground part of three species of genus of Symphytum.

\section{Materials and methodology}

Plant raw material collected from the experimental collections of Cultural Flora department of M.M. Gryshko National Botanical Garden of the NAS of Ukraine. It were investigated dried abouve-ground part of plants of Symphytum species: Symphytum officinale, Symphytum caucasicum, Symphytum $\times$ uplandicum Nyman. Plant material was took at stage of spring vegetation, stem growth, budding, blossoming, fruitage. Investigation of total antioxidant activity (TAA) carried out in Institute of Biodiversity Conservation and Biosafety, Slovak University of Agriculture in Nitra (Slovak Republic). TAA of the methanolic, ethanolic and aqueous extracts was determined according to Brand-Williams et al. (1995) against DPPH radical (2.2-diphenyl-1-picrylhydrazyl) (Brand-Williams et al., 1995). The procedure of determination of optical density measured with spectrophotometer Genesis-20 at wavelength $515 \mathrm{~nm}$. Dry mass $(1 \mathrm{~g}$ ) of investigated plants mixed with $25 \mathrm{~mL}$ of solvent. Extraction was carried out with methanol, ethanol and water during 12 hours with constant stirring on shaker. Antioxidant solution in solvent $(0.1 \mathrm{~mL}$ ) was added to $3.9 \mathrm{~mL}$ of methanol DPPH · solution ( $25 \mathrm{mg}$ per $100 \mathrm{~mL}$ of methanol with further delution). Absorbance of radical solution was in range $0.700-0.800$. Optical density of the solution was measured after adding sample immediately and after 10 min of incubation in thedark. Mean values of three replicates and standard deviations are given in Table 1-3.

\section{Results and discussion}

The antioxidant activity of plant extracts is of particular interest both of their beneficial physiological activity on human cells and the potential they have to replace synthetic antioxidants used in foodstuff (Amarowicz, 1999). Most of the methods of determination of total antioxidant activity characterize the ability of the tested compound or product to scavenge free radicals and to complex metal ions driving the oxidation process (Tirzitis and Bartosz, 2010). The DPPH method is rapid, simple, accurate and inexpensive assay for measuring the ability of different compounds to act as free radical scavengers (Marinova and Batchvarov, 2011).

For centuries, Symphytum officinale (comfrey) has been used as a traditional medicinal plant for the treatment of painful muscule and joint complaints. Comfrey has also been used in veterinary medicine. The therapeutic properties of comfrey are based on its anti-inflammatory and analgesic effect. These plants also stimulate granulation and tissue regeneration, and supports callus formation (Staiger, 2012). As shown in Table 1 methanol extracts of above-ground part of Symphytum asperum was in range from 73.59 to 79.65 depending on stage of growth.

Aqueous extracts had antiradical scavenging in range from 59.64 to $76.15 \%$. The lowest result of inhibition shown ethanol extracts of investigated plants during vegetation 17.53-36.31\%. Methanolic extract showed the most antioxidant activity at the period of fruitage, ethanolic - at spring vegetation, aqueous - at stem growth. 
Table 1 Antioxidant activity of different extracts of Symphytum asperum Lepech. during the vegetation, $\%$ of inhibition

\begin{tabular}{|l|c|c|c|c|c|c|}
\hline \multirow{2}{*}{ Phase of growing } & \multicolumn{2}{|c|}{ Methanol extracts } & \multicolumn{2}{c|}{ Ethanol extracts } & \multicolumn{2}{c|}{ Aqueous extracts } \\
\cline { 2 - 7 } & $\mathbf{m}$ & $\sigma$ & $\mathbf{m}$ & $\sigma$ & $\mathbf{m}$ & $\sigma$ \\
\hline Spring vegetation & 73.59 & 1.03 & 36.31 & 2.89 & 59.64 & 0.47 \\
\hline Stem growth & 78.04 & 3.23 & 26.78 & 1.29 & 76.15 & 0.34 \\
\hline Budding & 78.73 & 1.12 & 17.53 & 0.88 & 72.67 & 2.70 \\
\hline Blossoming & 75.92 & 0.98 & 25.16 & 1.84 & 62.99 & 1.13 \\
\hline Fruitage & 79.65 & 0.74 & 19.97 & 0.34 & 67.65 & 1.04 \\
\hline
\end{tabular}

$\mathrm{m}$ - mean values, $\sigma$-standard deviation

According to Vergun et al. (2014) antioxidant activity of shoots in the end of vegetation in extracts of Symphytum asperum was $87.34 \%$ (methanolic extracts) and $50.83 \%$ (water extracts).

In Table 2 represented the TAA of different extracts of plant raw material of Symphytum caucasicum. Methanol extracts inhibited solution of radical in range from 75.48 to $80.81 \%$, ethanol extracts - from 22.61 to $73.99 \%$ and aqueous extracts - from 67.46 to $74.45 \%$.

Table 2 Antioxidant activity of different extracts of Symphytum caucasicum Bieb. during the vegetation, $\%$ of inhibition

\begin{tabular}{|l|c|c|c|c|c|c|}
\hline \multirow{2}{*}{ Phase of growing } & \multicolumn{2}{|c|}{ Methanol extracts } & \multicolumn{2}{c|}{ Ethanol extracts } & \multicolumn{2}{c|}{ Aqueous extracts } \\
\cline { 2 - 7 } & $\mathbf{m}$ & $\sigma$ & $\mathbf{m}$ & $\sigma$ & $\mathbf{m}$ & $\sigma$ \\
\hline Spring vegetation & 80.81 & 0.19 & 73.99 & 1.48 & 73.94 & 0.98 \\
\hline Stem growth & 78.08 & 1.88 & 53.64 & 0.60 & 68.91 & 1.58 \\
\hline Budding & 75.48 & 2.23 & 33.28 & 0.92 & 67.46 & 1.84 \\
\hline Blossoming & 79.28 & 1.24 & 22.61 & 1.46 & 74.45 & 3.03 \\
\hline Fruitage & 78.38 & 0.24 & 36.19 & 1.48 & 69.59 & 1.52 \\
\hline
\end{tabular}

$m$ - mean values, $\sigma$-standard deviation

As reported Badridze et al. (2013), the total antioxidant activity of leaves extracts of Symphytum caucasicum in ethanol was $27.5 \%$. In methanolic extracts of leaves of these plants in the end of vegetation, as reported Vergun et al. (2014), inhibition of free radical was 52.64\%, in water extracts $57.43 \%$. Methanolic extracts of above-ground part of Symphytum caucasicum during vegetation showed antioxidant activity $75-80 \%$, aqueous $-67-74 \%$. It should be noted for ethanolic extracts different signs for different stages. From the start of vegetation to blossoming stage antiradical activity decreases from 73.99 to $22.61 \%$ and in the stage of fruitage increase to $36.19 \%$.

Table 3 has demonstrated that antioxidant activity of the methanol extracts of Symphytum uplandicum during vegetation was in range from 16.24 to 79.18 , ethanol extracts - from 5.64 to 21.06 and aqueous extracts - from 17.23 to $60.58 \%$. 
Table 3 Antioxidant activity of different extracts of Symphytum $\times$ uplandicum Nyman during the vegetation, $\%$ of inhibition

\begin{tabular}{|l|c|c|c|c|c|c|}
\hline \multirow{2}{*}{ Phase of growing } & \multicolumn{2}{|c|}{ Methanol extracts } & \multicolumn{2}{c|}{ Ethanol extracts } & \multicolumn{2}{c|}{ Aqueous extracts } \\
\cline { 2 - 6 } & $\mathbf{m}$ & $\sigma$ & $\mathbf{m}$ & $\sigma$ & $\mathbf{m}$ & $\sigma$ \\
\hline Spring vegetation & 77.95 & 1.70 & 10.61 & 1.10 & 55.47 & 1.40 \\
\hline Stem growth & 67.44 & 0.66 & 11.99 & 0.54 & 17.23 & 2.57 \\
\hline Budding & 79.18 & 1.46 & 21.06 & 0.46 & 60.58 & 1.04 \\
\hline Blossoming & 16.24 & 0.92 & 5.64 & 0.32 & 53.87 & 0.88 \\
\hline Fruitage & 26.37 & 2.51 & 5.67 & 0.40 & 37.86 & 2.81 \\
\hline
\end{tabular}

$\mathrm{m}$ - mean values, $\sigma$ - standard deviation

As showed our previous data the antioxidant activity of leaves of Symphytum $\times$ uplandicum in the end of vegetation was $58.32 \%$ in methanolic extracts and $58.98 \%$ - in water extracts (Vergun et al., 2014).

It's should be noted that among investigated plants Symphytum $\times$ uplandicum showed the most variable result in different extracts during vegetation. In spring vegetation in methanolic extracts it was 4.7 times more comparing with blossoming stage. In ethanolic extracts its increases from spring vegetation to budding and from budding to blossoming decreases again. In aqueous extracts peak of inhibition was noted in the budding stage, from budding to fruitage its decreases. The lowest sign identified in steam growth period.

\section{Conclusions}

Thus, the different extracts of dry plant raw material of Symphytum L. species were investigated by DPPH-method to identify antiradical scavenging. The TAA of methanolic extracts was in range from $16.24 \%$ in blossoming stage (Symphytum $\times$ uplandicum) to $80.81 \%$ in stage of spring vegetation (Symphytum caucasicum). The ethanolic extracts demonstrated the TAA in range from $5.64 \%$ in blossoming stage (Symphytum $\times$ uplandicum) to $73.99 \%$ in spring vegetation stage (Symphytum caucasicum). I the aqueous extracts was identified the TAA in range from $17.23 \%$ in stage of stem growth (Symphytum $\times$ uplandicum) to $76.15 \%$ in stage of stem growth (Symphytum asperum). Summarizing the obtained data it should be noted that for investigated plants of genus of Symphytum the radical inhibition by DPPH-method was $5.64-80.81 \%$ depending on extract solution that allows use it as potential antioxidant source.

\section{Acknowledgments}

The publication was prepared with the active participation of researchers involved in the International network AgroBioNet of the Institutions and researchers for realization of research, education and development program «Agrobiodiversity for improving nutrition, health and life quality» and within the project ITEBIO (ITMS 26220220115).

\section{References}

Alkan, F.U., Anlas, C., Ustiner, O., Bakirel, T., Sari, A.B. 2014. Antioxidant and proliferative effects of aqueous and ethanolic extracts of Symphytum officinale on $3 T 3$ Swiss albino mouse fibroblast cell line. Asian Journal of Plant Science and Research, vol. 4, no. 4, p. 62-68. 
Amarowicz, R., Barl, B., Pegg, R.B. 1999. Potential natural antioxidants from Saskatchewan indigenous plants. Journal of Food Lipids, vol. 6, p. 317-329.

Badridze, G., Kacharova, N., Chkhubianishvili, E., Rapava, L., Kikvidze, M., Chigladze, L., Chanishvili, S. 2013. Content of antioxidants in leaves of some plants of Tbilisi environs. Bulletin of the Georgian National Academy of Sciences, vol. 7, no. 3, p. 106-111.

Barbakdze, V.V., Mulkidzhanyan, K.G., Merlani, M.I., Gogilashvili, L.M., Amiranashvili, L.Sh., Shaburishvili, E.K. 2011. Extraction, composition, and the antioxidant and anticomplement avtivities of high molecular weight fractions from the leaves of Symphytum asperum and S. caucasicum. Pharmaceutical Chemistry Journal, vol. 44, no. 11, p. 604-607.

Brand-Williams, W., Cuvelier, M.E., Berset, C. 1995. Use of a free radical method to evaluate antioxidant activity. LWT - Food Science and Technology, vol. 28, p. 25-30.

Castro, A.H.F., Young, M.C.M., Alvarenga, A.A., Alves, J.D. 2001. Influence of photoperiod on the accumulation of allantoin in comfrey plants. Brazilian Journal of Plant Physiology, vol. 13, no. 1, p. 49-54.

Marinova, G., Batchvarov, V. 2011. Evaluation of the methods for determination of the free radical scavenging activity by DPPH. Bulgarian Journal of Agricultural Science, vol. 17, no. 1, p. 11-24.

Paun, G., Neagu, E., Litescu, S.C., Rotinberg, P., Radu, G.L. 2012. Application of membrane processes for the concentration of Symphytum officinale and Geranium robertianum extracts to obtain compounds with high anti-oxidative activity. Journal of the Serbian Chemical Society, vol. 77, no. 9, p. 1191-1203. DOI: 10.2298/JSC120106021P

Puertas-Mejia, C.M.A., Zuleta-Montoya, L.J.F., Rivera-Echeverry, L.F. 2012. In vitro antioxidant capacity of comfrey (Symphytum officinale L.). Revista Cubana de Plantas Medicinales, vol. 17, no. 1, p. 30-36.

Roman Paun, G., Neagu, E., Moroeanu, V., Radu, G.L. 2008. Concentration of Symphytum officinale extracts with cytostatic activity by tangential flow ultrafiltration. Roumanian Biotechnological Letters, vol. 13, no. 6, p. 4008-4013.

Savic, V., Nikolic, V., Stanojevic, L., Ilic, D., Stankovic, B. 2012. Extraction kinetics and antioxidant activity of an aqueous extract from comfrey root (Symphytum officinale L.). Advanced Technologies, vol. 1, no. 2, p. 41-47.

Staiger, C. 2012. Comfrey: a clinical overview. Phytotherapy Research, vol. 26, p. 1441-1448. DOI: 10.1002/ ptr.4612

Stef, D.-S., Gergen, I., Ioan-Trasca, T., Stef, L., Pop, C., Harmanescu, M., Biron, R., Pet, E. 2010. Evaluation of 33 medicinal plant extracts for the antioxidant capacity and total phenols. Journal of Food, Agriculture and Environment, vol. 8, no. 3-4, p. 207-210.

Stef,D.-S.,Gergen,I.,Stef,L.,Harmanescu,M.,Pop,C.,Druga,M.,Bujanca, G.,Popa, M.2010.Determination ofthe macro elements content of some medicinal herbs. Animal Science and Biotechnologies, vol. 43, no. 1, p. 122-126.

Tirzitis, G., Grzegorz, B. 2010. Determination of antiradical ant antioxidant activity: basic principles and new insights. Acta Biochimica Polonica, vol. 57, no. 1, p. 139-142.

Tahirovic, I., Kozljak, M., Toromanovic, J., Copra-Janicijevic, A., Klepo, L., Topcagic, A., Demirovic, H. 2014. Total phenolic content and antioxidant capacity in infusions of various herbal teas. Bulletin of the Chemists and Technologists of Bosnia and Herzegovina, vol. 42, p. 51-55.

Vergun, O.M. 2008. The content of free amino acids and photosynthetic pigments of Symphytum L. species in Ukrainian Northern Forest-Steppe. Scientific Bulletin of Chernivtsi University, vol. 416, p. 156-161.

Vergun, E.N., Rakhmetov, D.B. 2013. Total content of sugars and ascorbic acid in Symphytum L. species during flowering period. Non-traditional, New and Forgotten Plant Species: Scientific and Practical Aspects of Cultivation. Kyiv: Veles, p. 374-377.

Vergun, E., Rakhmetov, D., Brindza, J. 2014. The biological aspects of investigation of genus Symphytum L. Inovacie technologii specialnych vyrobkov biopotravin pre zdravu vyzivu l'udi: zbornik vedeckych prac a vysledkov. Nitra, 2014, p. 269-277. 